\title{
Making An Apple Motif On Painted Hijab Originated From Malang For Female Prisoners
}

\author{
Selena Johanna Putri, Fira Dia Ayu Candra, Nurul Hidayah, Agus Hery Supadmi Irianti \\ Department of Industrial Technology \\ Universitas Negeri Malang \\ Malang, Indonesia \\ agus.hery.ft@um.ac.id
}

\begin{abstract}
Painted-hijab training which conducted in correctional institution for women in Sukun, Malang, was followed by 30 prisoners. This training aimed to give skill training for prisoner after they are free from punishment. After attending this training, it is possible for the participants to create new job demand and to apply their ability when they go back to society. This Painted-hijab training has three sessions. The first is lecture and question-and-answer session. The materials about equipments and materials for painting on hijab, elements and principles of design, motif of design and hand painting technique are explained here. In this session, the participants are allowed to ask questions if there are still unclear explanations for them. The second session is paintedhijab demonstration about painted-hijab making processes. The last session is job training and assignment. The participants create painted-hijab in the real hijab medium in the job training session. Furthermore, assignment is given out of training session time. This training produced 30 hijab pieces with apple motif as the symbol of Malang City in a different placement.
\end{abstract}

\section{Keywords-Apple motif; painted hijab; prisoner}

\section{INTRODUCTION}

Apple is a kind of fruits that become one of the mark features of Malang and Batu City, because in general, apples can only grow in an environment having a low temperature. Therefore many products build from the basic ingredients of apples. Most of these productstends to food and beverages section, so it is appears a lot of food which is the mark of the Malang City with the original material that is anapples. It is shows that the importantly to leave an impression against the Malang City with a product which will last a long time and can be enjoyed visually in quite a long time. By paying attention to these matters then it is emerged a motif which is shows the special characteristic of Malang Citythat is an apples.
According to Big Indonesian Dictionary [1] motif is a pattern or style, meanwhile according to the Encyclopedia of Indonesia [2] explained that the motive is the base theme of an art. In the manufacture of patterns it is required the elements of the design. According to Sumaryati [3] there are 7 elements of design, they are line, plane, shape, texture, colours, dark-light and direction. Beside of paying attention to the elements, the pattern making should also be based on the design principles. According to Sumaryati [3], The Design Principle is a guide how to compose the elements in the pattern design of an image. According to Ernawati [4], the Design Principles include proportion, balance, rhythm, harmony, accent, unity. Inspired from the shape of an apple motif is made by using the method of Stylized. Stylized is styling over the depiction of natural forms into the shape ornamental with not leaving the character of its original form.

A stylized Apple with a show apple in a form that is already open, we would like to show that the Malang City is welcomed in no matter whocomes both it is domestic nor foreign tourists. An apples is shaped to resemble flowers, people may unaware this shape before, that apples areable to be formed as well and have the aesthetic value, more than that we want to show the similarities of Malang City and an apple even if looked like simple on the outside but it keeps all the beautiful shapes inside. The excused why Romebeauty apple was choosen is due to the type of apples that are widely produced by local farmers in Malang.

The technique of making an apples motif is given to inmates of Correctional Institutions Women's Class II A Malang in the form of trainings. According to Gomes [5] Training is any attempt to improve the performance of workers in a particular job are to be the responsibility or the work which has relation to his work. According to Lamria sandy h. Marbun [6], Training has several distinctive features, namely (1) training focuses on skills; (2) on the training it is expected that the participants can improve their skills through a process of learning; (3) in a training practice is very important, each participant should be given the opportunity to do practice as much as possible. This practice 
is a form of application of the knowledge given to them; (4) training given in the working time of trainees; (5) training is given at a time that is relatively short. The application of the apples motif is done with the portrayal technique. According to the Soedarso $\mathrm{Sp}$ [7] the Portrayal is a branch of art that is expressed in this way is manifested through the work of the two dimensional dima principal elements in the work of the two-dimensional is line and color .

The training manufacture of hijab painting are able to bring the skills to the inmates of Correctional Institutions Women's Class II A Malang. This training focuses on providing skills to the female inmates so that they can create their own jobs after their return to life in society. The skills training is done in for 2 days with participantsof 30 people. Skills training is done with the providing of materials, demonstration and practice work. The material is given the form of (1) knowledge about tools and materials; (2) knowledge of elements, principles and layout design motif. (3) knowledge about the techniques of making design motifs; (4) knowledge about painting technique hand Painting.; (5) entrepreneurship materials. Then the demonstration will be conducted by the speaker.

\section{METHOD}

The methods used in the activities of vocational Training are the Manufacture Hijab Painting Women in Prisoln Sukun Malang is face to face (face to face) and tutorial with training methods work and assignments

\section{A. Training methods work and assignment}

Wexly and Yulk [8] proposed that : "Training and development are term is referring to planned efforts designed to facilitate the acquisition of relevant skills, knowledge and attitudes by organizations members. Development focuses more on improving the decision making and human relations skills and the presentation of a more factual and narrow subject matter". Wexly and Yulk's opinions explained that training and development is something that refers to things associated with the efforts of the planning undertaken to achieve the mastery of skills.

Training as an activity that is meant to improve and develop the attitude, behaviors, skills, and knowledge of its employees in accordance with the wishes of the company. Training is not limited only to developing the skill solely and yet growing namely to reduce the time of learning in order to become more competent, reducing the error at once self-adjustment prior to direct work [9]

From the various opinions that have been mentioned before it can be concluded that job training is a way used to provide and enhance skills, improve skills and enhance performance by way of improving the expertise, knowledge, skills, attitudes and behaviorwhich are needed to carry out to the work area.
The general purposes of job training according to Moekijat [10] is 1) to develop expertise so that the work can be completed more quickly and effectively, 2) to develop knowledge so that the work can be complete rationality, 3) to develop attitudes that lead to cooperation with friends and staff leadership. The advantages of the job training methods is to give the opportunity to students to develop their potential or capabilities optimally. Meanwhile the deficiency of the job training methodsis that demanded a great responsibility to the training supervisor to examine and provide a feedback on the exercises which is done by the learners.

This job training methods implemented at the time of the training participants makes the sample of hijab painting and created the product hijab in the proper media. The manufacture of the samples was aimed as a media exercise to the participants of the training which is never been painted on the hijab before. The manufacture of these samples as a self-adjustment media before they applying directly on the hijab and to minimize the error which is done before making the proper product of hijab. The sample of hijab painting utilizingaEro Fabric sized $25 \times 25 \mathrm{~cm}$ which are already drawn with stylized anapples motif. The step of samples manufactured is delivered after the all the material get done already. The tutorial of making hijab painting is directly given by the trainer team to the participants.

The method of assignment or recitation according to the Imansjah Alipandie [11] is a way of teaching which is done by giving special assignments to students to do something outside of school hours. The implementation of these tasks can be done at home, the library, the laboratory, and the results of the task can be accounted for by the learners.

According To Sudirman. N, [12] understanding of the methods of assignment /recitation is a way of presenting the material of the lesson where the teacher (instructor) give a specific task so that learners perform the learning activities, meanwhile according to Slameto [13] proposed that the assignment method is a way of delivering the lesson material with the task to learners to be done with the given time range and the result should be accountable to the teacher (instructor).

From some opinions above it can be concluded that the method of assignment or recitation is somekind of peers to the participants of the training which is done on the outside of training hours. The task can be done anywhere with a certain time span and the result of the task can be accounted for on the assignor (the instructor).

The assignment is done when the trainee working on the creation of a sample of hijab painting. Because of, there are so many material delivered at the time of training, the sample making can be done by the participants of the training outside of the training hours. The granting of this 
task is aims to foster a sense of responsibility on the participants of the training will work or the obligation that they have to finish.

After the sampling process is completed, the next stage is the manufacture of products hijab painting which are using Ero Fabric with a square shapes with a size of $115 \mathrm{~cm}$ $\mathrm{x} 115 \mathrm{~cm}$. The selection of motifs used in the manufacture of products of hijab is namely the motif of apples that have been in the stylized so as to produce the new patterns but still there are the hallmark of the apple. There are 4 placement of the motifs in this training, namely the placement of the motif in the middle of the hijab or center, the placement of motifs on the ends of the hijab or the motive angle, the motive of the hoarse and the combination of the motif center with the motive angle. Each training participant to paint one piece hijab with the placement of different motifs depending on the choice of each participant so that there is a wide range of variations of the hijab though with the same motif

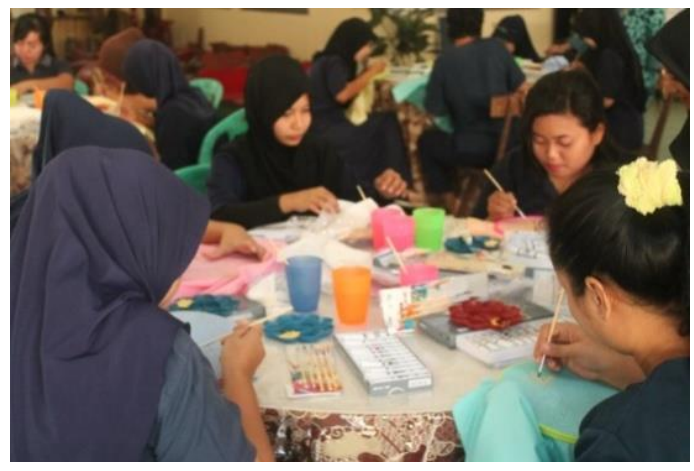

Fig. 1. Training work Manufacture of Hijab Lukis

\section{RESULTS AND DISCUSSION}

The result of this training is produce of the apples motif "rome beauty" in hijab painting. The Motif of the apple is placed in 4 different parts namely, the placement of the motif in the middle of the hijab or center, the placement of motifs on the ends of the hijab or the motive angle, the motive of the hoarse and the combination of the motif center with the motive angle. Each participants of the training paint one piece of hijab with the different placement motifs according to their ownwill so that there is a wide range of variations of the hijab though with the same motif.

This training was held for two days. This training is carried out with very satisfactory feeling. The satisfactory indicators can be seen from the enthusiastic participants. The participant enthusiasm indicators of such training can be seen from the amount trainees who join from beginning until the end is not reducing. The next indicator is the message and impression by the participants of the training. The message and the impression of the participants is they demand to held the training again and request to stop by. In addition, participants of the training also considers the training is interesting, because it is held by the first time for them.

\section{B. Product Training}

The training result created 30 pieces hijab painting. The difference of results of the product hijab painting include neat and pretty neat. The product evaluation based on the standart of assestment of counseling team. The results of product assessment is used to evaluate training and consideration to follow up the next program. The result evaluation of the hijab production is finished on time, 26 product hijab painting resulting neatly and 27 hijab painting in accordance with the design specified. With these results the average results from product training is feasible for our buyer.

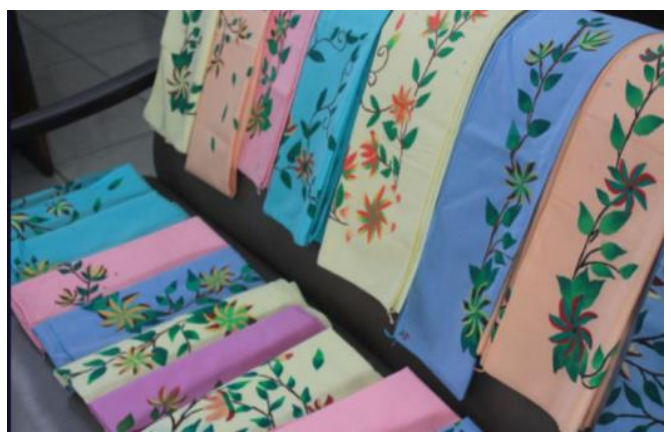

Fig. 2. Results so product training

TABLE I. STANDARD PRODUCT ASSESSMENT HIJAB LUKIS

\begin{tabular}{|l|l|c|c|c|c|c|c|c|c|c|}
\hline & & \multicolumn{2}{|c|}{ Time } & \multicolumn{3}{c|}{ Neatnes } & \multicolumn{2}{c|}{ Design } \\
\hline No. & Name & F & M & S & N & PN & LA & C & Q & N \\
\hline 1. & Trainees 1 & $\checkmark$ & & & $\checkmark$ & & & $\checkmark$ & & \\
\hline 2. & Trainees 2 & $\checkmark$ & & $\checkmark$ & & & $\checkmark$ & & \\
\hline 3. & Trainees 3 & $\checkmark$ & & $\checkmark$ & & & & $\checkmark$ & \\
\hline 4. & Trainees 4 & $\checkmark$ & & $\checkmark$ & & & $\checkmark$ & & \\
\hline 5. & Trainees 5 & $\checkmark$ & & $\checkmark$ & & & $\checkmark$ & & \\
\hline 6. & Trainees 6 & $\checkmark$ & & & $\checkmark$ & & $\checkmark$ & & \\
\hline 7. & Trainees 7 & $\checkmark$ & & $\checkmark$ & & & $\checkmark$ & & \\
\hline 8. & Trainees 8 & $\checkmark$ & & & $\checkmark$ & & $\checkmark$ & & \\
\hline 9. & Trainees 9 & $\checkmark$ & & $\checkmark$ & & & $\checkmark$ & & \\
\hline 10 & $\begin{array}{l}\text { Trainees } \\
10\end{array}$ & $\checkmark$ & & $\checkmark$ & & & $\checkmark$ & & \\
\hline
\end{tabular}


TABLE I. CONT

\begin{tabular}{|c|c|c|c|c|c|c|c|c|c|c|}
\hline & & \multicolumn{3}{|c|}{ Time } & \multicolumn{3}{|c|}{ Neatnes } & \multicolumn{3}{|c|}{ Design } \\
\hline No. & Name & $\mathbf{F}$ & $\mathbf{M}$ & $\mathbf{S}$ & $\mathbf{N}$ & PN & LA & & $\mathbf{Q}$ & $\begin{array}{l}\mathbf{N} \\
\mathbf{A}\end{array}$ \\
\hline 11 & Trainees 11 & $\checkmark$ & & & $\checkmark$ & & & $\checkmark$ & & \\
\hline 12 & Trainees 12 & $\checkmark$ & & & $\checkmark$ & & & $\checkmark$ & & \\
\hline 13 & Trainees 13 & $\checkmark$ & & & & $\checkmark$ & & $\checkmark$ & & \\
\hline 14 & Trainees 14 & $\checkmark$ & & & $\checkmark$ & & & $\checkmark$ & & \\
\hline 15 & Trainees 15 & $\checkmark$ & & & $\checkmark$ & & & $\checkmark$ & & \\
\hline 16 & Trainees 16 & $\checkmark$ & & & $\checkmark$ & & & $\checkmark$ & & \\
\hline 17 & Trainees 17 & $\checkmark$ & & & $\checkmark$ & & & & & \\
\hline 18 & Trainees 18 & $\checkmark$ & & & $\checkmark$ & & & $\checkmark$ & & \\
\hline 19 & Trainees 19 & $\checkmark$ & & & $\checkmark$ & & & $\checkmark$ & & \\
\hline 20 & Trainees 20 & $\checkmark$ & & & $\checkmark$ & & & $\checkmark$ & & \\
\hline 21 & Trainees 21 & $\checkmark$ & & & $\checkmark$ & & & $\checkmark$ & & \\
\hline 22 & Trainees 22 & $\checkmark$ & & & $\checkmark$ & & & $\checkmark$ & & \\
\hline 23 & Trainees 23 & $\checkmark$ & & & $\checkmark$ & & & $\checkmark$ & & \\
\hline 24 & Trainees 24 & & & & $\checkmark$ & & & & & \\
\hline 25 & Trainees 25 & $\checkmark$ & & & & $\checkmark$ & & $\checkmark$ & & \\
\hline 26 & Trainees 26 & $\checkmark$ & & & $\checkmark$ & & & $\checkmark$ & & \\
\hline 27 & Trainees 27 & $\checkmark$ & & & $\checkmark$ & & & $\checkmark$ & & \\
\hline 28 & Trainees 28 & $\checkmark$ & & & $\checkmark$ & & & $\checkmark$ & & \\
\hline 29 & Trainees 29 & $\checkmark$ & & & $\checkmark$ & & & $\checkmark$ & & \\
\hline 30 & Trainees 30 & $\checkmark$ & & & $\checkmark$ & & & $\checkmark$ & & \\
\hline
\end{tabular}

\section{Product outside of training}

This training has been published in the newspaper twice. This training also produce the articles in TEKNA entitled "Skills Training Manufacture of Hijab Painting To Residents of Women Inmatein Sukun Malang" so that the article can be used as a reference by the general public. This training also produce the proceedings of the international seminar iconhomecs titled "Making An Apple Motif On Painted Hijab Originated From Malang For Female Inmate".
This training also has the potential to earn copyright. The copyright of the motif formedas Rome Beauty Apples. The training team uses Rome Beauty Apples as motifs because it is trademark apples from Malang. This Motif is exclusively designed by the Implementing Training Team. Todays, the training team has been registered the IPR motif Apples Rome Beauty which are in waiting period for the nomination process. By obtaining copyright, the training team will get royalties if the motifs that already patented so that other people will not be able to use the pattern without permission of the creator motive.

\section{CONCLUSION}

The apple is the fruit which became one of the hallmark of the city of Malang. Products which are utilizing apples as the based material may have a lot in the encounter. Most of these products classified in the field of food and beverages, so it is appears a lot of food which is the mark of the Malang City with the original material that is an apples.. But yet there are people who have the idea to make the motif of apples. So by paying attention to these things then appear a creation motif to show the hallmark of Malang City that is apples. This Motif is designed to also not only to consider the value of its aesthetic but also to create meaning. A stylized Apple with a show apple in a form that is already open, we want to show that the city of malang is welcomed in no matter who comes both it is domestic nor foreign tourists.

The technique of pattern Making apples of Malang is given to inmates of Correctional Institutions Women's Class II A Malang in the form of training. Training hijab painting was held over two days. The training went well because of the participation of prison authorities who have supported the implementation of Training Hijab Painting Women in Prison Sukun Malang. The participation of prison impression is seen with Kasie Activities of the Working Women Prisons Sukun Malang who took the time to open and close the training as well as always follow for training implemented. The high enthusiastic from training participants can be seen from several indicators, namely the number of training participants from the beginning to the end of the training and not reduced it means that the participants complete presence and enthusiastic about practice and theory, the completion of products on time every participant is also an indicator of the enthusiasm of the participants.

Given the enthusiasm of the participants, the results of the testimonials of the participants, then these activities need to be escorted to become at the formation of the business. So by that meaning an advice to prison authorities, in order to facilitate the follow-up activities to produce a product that is worth selling. For the training team, in order to continue mentoring the inmates to be able to produce products 
independently. So the inmates have not find difficulties and confused in finding a job because have been able to make the products hijab painting that can be sold to provide additional income or livelihood.

\section{REFERENCES}

[1] Kamus Besar Bahasa Indonesia, 2017 (online), (https://kbbi.kemdikbud.go.id/entri/motif).

[2] Pola , 2017 (online), (http://id.wikipedia.org/wiki/Pola.html).

[3] Sumaryati, Catri, Dasar Desain II (DirektoratPembinaan Kursus Dan Pelatihan, Jakarta, 2013

[4] Ernawati,dkk, Tata Busana Jilid 2 (Direktorat Pembinaan Sekolah Menengah Kejuruan, Jakarta, 2008).

[5] Gomes, Faustino Cardoso, Manajemn Sumber Daya Manusia (Andi Offset, Yogyakarta, 2003).

[6] Marbun, Lamria Louri, Gambaran Sistem Pelayanan Pada Unit Diklat Rumah Sakit Metropolitan Medical Centre Jakarta Tahun 2009 (Fakultas Kesehatan Masyarakat Universitas Indonesia, Jakarta, 2009).

[7] Soedarso, Sp, 1990. Tinjauan Seni, (Saku Dayar Sarana, Yogyakarta, 1990).

[8] A.A Anwar Prabu Mangkunegara, Manajemen Sumber Daya Manusia (PT. Remaja Rosdakarya, Bandung, 2009).

[9] Alex S. Nitisemito, Menejemen Personalia (Graha Indonesia, Jakarta,1996).

[10] Moekijat, Latihan Dan Pengembangan Layanan Pegawai (Mandiri Maju, Bandung, 1991).

[11] Alipandie, Imansvah, Didaktik Metode Pendidikan (Usaha Nasional, Surabaya, 1984).

[12] Sudirman, N, Ilmu Pendidikan(Remaja Rosdakarya, Bandung, 1991).

[13] Slameto, Proses Belajar Mengajar Dalam Sistem Kredit (SKS) (Bumi Aksara, Jakarta, 1990). 